Teologia i Moralność, volumen 12(2017), numer 2(22)

doi: 10.14746/tim.2017.22.2.1

PAWEŁ BORTKIEWICZ

Uniwersytet im. Adama Mickiewicza w Poznaniu

Wydział Teologiczny

\title{
Głosić Ewangelię życia
}

Tytułowe słowa zaczerpnięte z encykliki św. Jana Pawła II Evangelium vitae $^{1}$ wskazują na priorytetowe zadanie Kościoła w aktualnym świecie naznaczonym degradacją życia ludzkiego. Nośność tego imperatywu wynika przede wszystkim ze współczesnych wyzwań wymierzonych przeciw życiu ludzkiemu. Jednak warto przede wszystkim zauważyć zawartość treściową samej Ewangelii życia, by dostrzec poprzez jej składowe, znaczenie i adekwatność treściową wobec elementów „kultury śmierci”. Warto także dostrzec wewnętrzne piękno papieskiego orędzia, które stanowi w swej istocie wspaniały hymn o miłości Boga i godności człowieka.

\section{Współczesny kontekst negujący życie jako dar}

Tematyka zagrożenia życia ludzkiego wpisuje się w całe pasmo dramaturgii ludzkich dziejów. Dlatego św. Jan Paweł II w swojej encyklice Evangelium vitae podjął temat demaskacji „kultury śmierci” na podstawie archetypu biblijnej postaci Kaina dopuszczającego się pierwszego aktu zbrodni na niewinnym człowieku - bracie. Świadom fenomenu działań przeciwnych życiu sięgających prehistorii i zarazem wpisanych w znaną historię ludzkich dziejów papież podkreślał jednak nowość aktualnej sytuacji:

1 Słowa te są zaczerpnięte $\mathrm{z}$ podtytułu poprzedzającego numer 80 i następne encykliki „ "Oznajmiamy wam, cośmy ujrzeli i usłyszeli» (1 J 1,3): głosić Ewangelię życia” - tekst encykliki za Encykliki Ojca Świętego Jana Pawła II, Kraków 2003, (dalej: EV wraz z numerem dokumentu) s. 839-937. 
pragniemy jednak zwrócić szczególną uwagę na inny rodzaj zagrożeń wymierzonych przeciw życiu poczętemu lub życiu, które zbliża się do końca: dostrzegamy w nich nowe aspekty, nieznane w przeszlości oraz problemy niezwyklej wagi, związane z faktem, że w świadomości zbiorowej te zamachy na życie tracą stopniowo charakter „przestępstwa” i w paradoksalny sposób zyskują status „prawa” (EV 11).

Istotnym elementem tej nowości są zatem dwa czynniki - jednym jest rozszerzenie zakresu „zamachów na ludzkie życie”2. Oznacza ono, pojawiające się w wyniku nowych czy nowatorskich działań biomedycznych poddanych wyłącznie rachunkowi utylitarnemu i zasadzie jakości życia, takie działania, jak: utylizacja tkanek płodowych i embrionów, niszczenie tzw. „zarodków nadliczbowych" w efekcie procedury sztucznego zapłodnienia in vitro, zagrożenia życia powstające $\mathrm{w}$ wyniku dążenia do pozyskiwania organów pojedynczych dla celów transplantacyjnych czy wreszcie problemy związane z konfrontacją prawa do życia z prawem do godnej śmierci w etapie finalnym ludzkiej egzystencji.

Drugim czynnikiem nowości odróżniającej czasy współczesne od archetypu Kaina jest uznanie tego, co było tradycyjnie traktowane jako ,przestępstwo” lub „patologia”, za „prawo” bądź „,normę”.

Jest to proces sam w sobie bardzo ciekawy, którego pierwszym etapem staje się promocja wolności oderwanej od prawdy. Jan Paweł II pisał: „wolność zapiera się samej siebie, zmierza do autodestrukcji i do zniszczenia drugiego człowieka, gdy przestaje uznawać i respektować konstytutywna więź, jaka łaczy ja z prawdq" (EV 19). Dodawał zarazem, że ten proces ma ogromne znaczenie społeczne - „ta koncepcja wolności prowadzi do glębokiego znieksztatcenia życia społecznego" (EV 20).

Można powiedzieć zatem, że u podstaw destrukcji współczesnego prawa stanowionego leży swoisty błąd antropologiczny - zakwestionowanie lub zafałszowanie prawdy o człowieku, osobie ludzkiej, prowadzi do ekstremalizacji zafałszowanej w ten sposób wolności. Trywialną i poniekąd wulgarną ilustracją tego procesu są znane w przestrzeni publicznej hasła „mój brzuch jest moją własnością” (i domyślnie „wolno mi robić z nim, co chcę”). Problemem jest najpierw to, że owo pojęcie „mój brzuch” oznacza faktycznie opis niezależnego podmiotu, nienarodzonego, ale realnie żyjącego człowieka. Takie zakłamanie prawdy uzdalnia do absolutyzacji wolności.

Błąd antropologiczny ma jednak dalsze i głębsze źródło. Święty Jan Paweł II wskazuje bardzo jednoznacznie, że trzeba poszukać go w sferze teologiczno-kulturowej. Można określić ją jako ,agnostycyzm zawiniony”:

${ }^{2}$ Por. szerzej na ten temat P. Bortkiewicz, W stużbie życia, t. 1: Demaskacja kultury śmierci, Niepokalanów 1999. 
Trzeba dojść do sedna dramatu, jaki przeżywa współczesny człowiek: jest nim osłabienie wrażliwości na Boga i człowieka, zjawisko typowe w kontekście społecznym i kulturowym zdominowanym przez sekularyzm, którego wpływy przenikają nawet do wnętrza wspólnot chrześcijańskich i wystawiają je na próbę. Kto poddaje się oddziaływaniu tej atmosfery, łatwo może się znaleźć w zamkniętym kole, które wciąga go niczym straszliwy wir: tracąc wrażliwość na Boga, traci się także wrażliwość na czlowieka, jego godność i życie (EV 21).

Raz jeszcze warto zwrócić uwagę na tę analizę zjawiska kultury śmierci w jej wieloaspektowości, a zarazem ogromnej logice destrukcji. Przykładem może być problem sztucznego zapłodnienia in vitro. Jego konstytutywnym elementem jest faktyczna eliminacja embrionów nadliczbowych, co oznacza działanie przeciwne życiu ludzkiemu. Jest zawsze wyrazem manipulacji człowiekiem, jego życiem dla realizacji własnych pragnień. Samo pojęcie „reprodukcji" adekwatne dla opisywanego zjawiska, a wypierane kamuflażowo we współczesnej terminologii (,technika sztucznej reprodukcji” jest zamieniana na pojęcie „metody leczenia niepłodności”) ilustruje adekwatnie potraktowanie człowieka jako „produktu” służącego zaspokojeniu arbitralnych dążeń $\mathrm{i}$ aspiracji dorosłych ludzi. Wreszcie, $\mathrm{w}$ tle zjawiska pojawia się odrzucenie niepłodności jako cierpienia i dążność do technologicznego „pokonania” „choroby”, które to zjawiska zyskują umocnienie w klimacie kulturowego laicyzmu i agnostycyzmu zawinionego.

Tak naszkicowana analiza zjawiska „kultury śmierci” domaga się przeciwdziałania w postaci „kultury życia”.

\section{Ewangelia miłości Boga do czlowieka}

Projekt kultury życia jest podniesiony przez św. Jana Pawła II do kategorii „Ewangelii życia”. Jej syntetyczne ujęcie przynosi już początek encykliki, gdzie papież pisał: „Ewangelia miłości Boga do człowieka, Ewangelia godności osoby i Ewangelia życia stanowia jedna i niepodzielna Ewangelię" (EV 2).

O ile przyjmiemy, że kultura śmierci zakłada u swoich korzeni „osłabienie wrażliwości na Boga", o tyle projekt Ewangelii życia zakłada u swoich podstaw proklamację „miłości Boga do człowieka”. Jej wyrazem najbardziej podstawowym jest fakt stworzenia - powołania człowieka do istnienia, co jest wyrazem miłości Boga do osoby ludzkiej.

Trzeba przy tym zauważyć, że wymiar stworzenia osoby w jej wizji jako podmiotu moralnego obejmuje nie tylko oczywiste odniesienie do faktu, że jesteśmy stworzeni przez Boga Ojca, ale także wyraża prawdę, że jesteśmy stworzeni przez Chrystusa i w Chrystusie. 
„Chrystus... już w samym objawieniu tajemnicy Ojca i Jego miłości objawia w pełni człowieka samemu człowiekowi i okazuje mu najwyższe jego powołanie” [KDK 22]. W Chrystusie „obraz Boga niewidzialnego” (Kol 1,15), człowiek został stworzony „na obraz i podobieństwo” Stwórcy. W Chrystusie, Odkupicielu i Zbawicielu, obraz Boży, zniekształcony w człowieku przez grzech pierwszy, został odnowiony w swoim pierwotnym pięknie i uszlachetniony łaską Bożą [por. KDK 22] $]^{3}$.

Tak pojęty stwórczy wymiar osoby jest fundamentem bezpośrednich relacji człowieka z Bogiem w Jezusie Chrystusie. Ukazuje także aktualną egzystencję człowieka jako egzystencję stworzenia Bożego. Egzystencja ludzka w swej całości pozostaje od Boga i w Bogu, a jednocześnie przez Chrystusa i w Chrystusie.

W perspektywie moralnej stworzenie jawi się jako akt mówienia Boga do człowieka. Mowa Boga dokonuje się dwojako:

- przez rzeczy stworzone (słowa wypowiedziane),

- przez człowieka (nie tylko jest to słowo wypowiedziane, ale i słowo mówiące, jako jedyne zdolne do mówienia od siebie, w konsekwencji zdolne do odpowiedzi).

Bóg, stwarzając człowieka, nazywa go (nadaje mu imię człowieka), to natomiast oznacza Boże wymaganie, by człowiek był i żeby był człowiekiem. Dialog Boga z człowiekiem dokonuje się nieustannie za pośrednictwem sumienia rozpoznającego głos Boga jako prawo. „Każdy człowiek jest zobowiązany do kierowania się tym prawem, które rozbrzmiewa w sumieniu i które wypełnia się w miłości Boga i bliźniego. Życie moralne świadczy o godności osoby"4. Człowiek w perspektywie stworzenia jawi się zatem jako naturalne wymaganie Boga, a równocześnie jako wolna i rozumna odpowiedź Bogu. Przykładem w tym względzie jest wzór Jezusa Chrystusa (por. 2 Kor 1,19-20).

Jednak najbardziej doniosłą prawdą objawioną w Biblii jest ta, która traktuje człowieka jako obraz Boga. Wyrażają ją dwa teksty z Księgi Rodzaju: Rdz 1,26-27 i Rdz 5,3. 9,65.

${ }^{3}$ Katechizm Kościoła katolickiego, Poznań 2009, (dalej: KKK) 1701.

${ }^{4}$ KKK 1706.

${ }^{5}$ Dzieje myśli teologicznej przyniosły szereg interpretacji dotyczących rozumienia $\mathrm{w}$ tych opisach „obrazu”:

1) św. Tomasz (STh III prologus), podsumowując dyskusje wcześniejszych pisarzy i ojców Kościoła (zwłaszcza Ireneusza i Augustyna), stwierdza, że być obrazem Boga jest właściwe dla człowieka jako istoty duchowej, wolnej i odpowiedzialnej. Bycie „obrazem” dotyczy tylko rozumu, a per modum vestigii może mieć zastosowanie także co do ciała; 
Sapiencjalny tekst: „Dla nieśmiertelności Bóg stworzył człowieka uczynił go obrazem (eikona) swej własnej wieczności [...]” (Mdr 2,26), jest dobitnym znakiem dowartościowania człowieka w myśli teologicznej Starego Testamentu. Myśl ta nie przesłania prawdy o tym, że ten obraz został przez samego człowieka zniszczony dziełem grzechu. Nowy Testament może podjąć ten temat. Człowiek przestaje być obrazem Boga na skutek własnego grzechu, ale może na nowo zyskać w sobie ten obraz dzięki nowemu stworzeniu w chrzcie $($ Kol 3,10). Dokonuje się to w wyniku działania Jezusa. Obraz Boga w Nowym Testamencie, w takim razie, zakłada powinność uczestniczenia w Chrystusie. To właśnie On jest przede wszystkim obrazem Boga (Kol 1,15).

Chrystus jest doskonałą ikoną Boga Niewidzialnego, co oznacza, że nie jest tylko wierną kopią, ale ma zalety oryginału i władny jest upodabniać się do oryginału, do Boga. W tekstach św. Pawła istnieją takie, które mówią o przyoblekaniu się w Chrystusa (por. Kol 3,10; Rz 13,14) ${ }^{6}$.

2) H. Gunkel na podstawie egzegezy tekstu Rdz 5,13 postawił tezę, że „obraz” jest zapisem relacji podobieństwa fizycznego między ojcem a synem. Jego zdaniem, zachodziło fizyczne (w kształcie i wyglądzie) podobieństwo człowieka do Boga. Można, mimo zastrzeżeń, wydobyć z tej myśli interesującą tezę, że podobieństwo do Boga dotyczy człowieka w jego konkretnej całości duchowo-cielesnej.

3) Współcześni egzegeci (np. G. von Rad) utrzymują, że cały człowiek, w swej strukturze psychofizycznej jest stworzony na obraz Boga.

4) Niektórzy egzegeci formułują tezę, że prawda o stworzeniu człowieka na obraz Boga wyraża sprawowaną przez człowieka nad stworzeniem władzę królewską. Pojęcie obrazu Bożego jest tutaj rozumiane nie statycznie, ale funkcjonalnie, jako zadanie, jako powierzona odpowiedzialność.

5) N. Lohfink w swoim studium stwierdza, że obraz Boży dotyczy nie tylko samego, indywidualnego człowieka, lecz całego stworzenia, które jest mocą ludzkiej pracy doprowadzone do swojej doskonałej piękności. Ono także jest kopią (Nachbild) przestrzeni promieniowania Bożego. Lohfink zauważa także, że człowiek jest stworzony na obraz Boga pracującego (i odpoczywającego). Ostatecznie ta kategoria pojęciowa służy nie tyle wywyższeniu człowieka, ile ukazaniu wielkiej i głębokiej więzi między stworzeniem a światem.

6) Westermann z kolei wykazuje, że stworzenie na obraz Boży ma na celu uzyskanie pewnego rezultatu mieszczącego się między Bogiem a człowiekiem (traktowanym w tej teorii jako cała ludzkość). Być obrazem to nie jest kwestia dodatkowego atrybutu stworzenia, ale to wyrażenie prawdy, że człowiek jest stworzeniem Boga.

Podsumowując wymienione teorie, można stwierdzić: „Pojęcie «obrazu Bożego» wyraża zarówno powszechną wolę zbawczą Boga względem każdego człowieka jak i wartość w sobie każdej osoby ludzkiej. [...]

Być obrazem znaczy, że człowiek nosi wpisaną w swoje być stworzeniem Bożym wolę stwórczą Boga, która jest planem zbawczym lub wezwaniem do dialogu. Być człowiekiem to być obrazem Bożym, to także relacja w cielesności istnienia.

Ludzkość ma ten cel: dialog z Bogiem. Ludzie nie są stworzeni dla innych celów [...], poza Bogiem. Bóg jednak nie jest celem, który czyni z człowieka narzędzie: człowiek jest jedynym stworzeniem, którego Bóg chciał dla niego samego" - A. Bonora, Człowiek obrazem Boga w Starym Testamencie, „Communio” (pol.) 2(1982) nr 2 (8), s. 13.

${ }^{6}$ Por. J.K. Pytel, Człowiek obrazem Boga w Nowym Testamencie, „Communio” (pol.) 2(1982) nr 2(8) s. 16-21. 
Temat naszej egzystencji w Chrystusie ma szczególne znaczenie dla teologii moralnej, stanowi wręcz zagadnienie usytuowane w centrum rozważań antropologicznych. Nie prezentując tutaj szczegółowego rozwinięcia tej kwestii, warto przypomnieć następujące teksty wypowiedzi Kościoła:

Tajemnica człowieka wyjaśnia się naprawdę dopiero w tajemnicy Słowa Wcielonego. Albowiem Adam, pierwszy człowiek był figurą przyszłego, mianowicie Chrystusa Pana. Chrystus, nowy Adam, już w samym objawieniu tajemnicy Ojca i Jego miłości objawia w pełni człowieka samemu człowiekowi i okazuje mu najwyższe jego powołanie. Nic więc dziwnego, że w Nim wyżej wspomniane prawdy znajdują swoje źródło i szczyt.

Ten, który jest „obrazem Boga niewidzialnego” (Kol 1,15), jest człowiekiem doskonałym, który przywróci synom Adama podobieństwo Boże, zniekształcone od czasu pierwszego grzechu. Skoro w nim przybrana natura nie ulega zniszczeniu, tym samym została ona wyniesiona również w nas do wysokiej godności. Albowiem On, Syn Boży, przez wcielenie swoje zjednoczył się jakoś z każdym człowiekiem. Ludzkimi rękoma pracował, ludzkim myślał umysłem, ludzką działał wolą, ludzkim sercem kochał, urodzony z Maryi Dziewicy, stał się prawdziwie jednym z nas, we wszystkim do nas podobny oprócz grzechu. Niewinny Baranek krwią swoją dobrowolnie wylaną wysłużył nam życie i w Nim Bóg pojednał nas ze sobą i między nami samymi oraz wyrwał z niewoli szatana i grzechu, tak że każdy z nas może wraz z Apostołem powiedzieć: Syn Boży ,umiłował mnie i wydał samego siebie za mnie" (Gal 2,20). Cierpiąc nie tylko dał przykład, byśmy szli w Jego ślady, lecz i otworzył nam nową drogę, którą jeśli idziemy, życie i śmierć doznają uświęcenia i nabierają nowego sensu.

Chrześcijanin zaś stawszy się podobnym do obrazu Syna, który jest Pierworodnym między wielu braćmi, otrzymuje ,pierwociny Ducha” (Rz 8,23), które czynią go zdolnym do wypełniania nowego prawa miłości. Przez tego Ducha, będącego „zadatkiem dziedzictwa” (Ef 1,14), cały człowiek wewnętrznie się odnawia aż do „odkupienia ciała” (Rz 8,23). Bo ,jeśli Duch tego, który wzbudził z martwych Jezusa Chrystusa, przebywa w was, ten, który z martwych wzbudził Jezusa Chrystusa, ożywi śmiertelne ciała wasze Duchem swym w was przebywającym" (Rz 8,11). Chrześcijanina przynagla z pewnością potrzeba i obowiązek walki ze złem wśród wielu utrapień, nie wyłączając śmierci, lecz włączony w tajemnicę paschalną, upodobniony do śmierci Chrystusa, podąży umocniony nadzieją ku zmartwychwstaniu?

W encyklice św. Jana Pawła II Redemptor hominis czytamy w numerze 10 zatytułowanym „Ludzki wymiar Tajemnicy Odkupienia”:

7 Sobór Watykański II, Konstytucja duszpasterska o Kościele w świecie współczesnym Gaudium et spes, Poznań 2005, 22. 
Człowiek nie może żyć bez miłości. Człowiek pozostaje dla siebie istotą niezrozumiałą, jego życie jest pozbawione sensu, jeśli nie objawi mu się Miłość, jeśli nie spotka się z Miłością, jeśli jej nie dotknie i nie uczyni w jakiś sposób swoją, jeśli nie znajdzie w niej żywego uczestnictwa. I dlatego właśnie Chrystus Odkupiciel, jak to już zostało powiedziane, „objawia w pełni człowieka samemu człowiekowi”. To jest ów jeśli tak wolno się wyrazić ludzki wymiar Tajemnicy Odkupienia. Człowiek odnajduje w nim swoją właściwą wielkość, godność i wartość swego człowieczeństwa. Człowiek zostaje w Tajemnicy Odkupienia na nowo potwierdzony, niejako wypowiedziany na nowo. Stworzony na nowo! „Nie ma już Żyda ani poganina, nie ma już niewolnika ani człowieka wolnego, nie ma już mężczyzny ani kobiety, wszyscy bowiem jesteście kimś jednym w Chrystusie Jezusie". Człowiek, który chce zrozumieć siebie do końca nie wedle jakichś tylko doraźnych, częściowych, czasem powierzchownych, a nawet pozornych kryteriów i miar swojej własnej istoty musi ze swoim niepokojem, niepewnością, a także słabością i grzesznością, ze swoim życiem i śmiercią, przybliżyć się do Chrystusa. Musi niejako w Niego wejść z sobą samym, musi sobie „przyswoić”, zasymilować całą rzeczywistość Wcielenia i Odkupienia, aby siebie odnaleźć. Jeśli dokona się w człowieku ów dogłębny proces, wówczas owocuje on nie tylko uwielbieniem Boga, ale także głębokim zdumieniem nad sobą samym. Jakąż wartość musi mieć w oczach Stwórcy człowiek, skoro zasłużył na takiego i tak potężnego „Odkupiciela”, skoro Bóg „Syna swego Jednorodzonego dał”, ażeby on, człowiek, „nie zginął, ale miał życie wieczne”.

Właśnie owo głębokie zdumienie wobec wartości i godności człowieka nazywa się Ewangelią, czyli Dobrą Nowiną. Nazywa się też chrześcijaństwem. Stanowi o posłannictwie Kościoła w świecie również, a może nawet szczególnie „W świecie współczesnym”.

Prawda teologiczna o człowieku stworzonym i odkupionym jest, w swej najgłębszej treści, prawdą o wyjątkowej wielkości człowieka, którą tradycja myśli Zachodu nazywa godnością. Trzeba zauważyć bardzo dobitnie z jednej strony fakt, że tak rozumiana godność ma charakter ontyczny, a nie uznaniowy. Oznacza to, że przysługuje każdemu człowiekowi ze względu na fakt bycia człowiekiem, a nie ze względu na uznanie jego wartości na jakimś etapie jego istnienia. $Z$ drugiej strony tak rozumiana godność ma charakter uniwersalny - przysługuje wszystkim ludziom, niezależnie od określanej w jakikolwiek sposób ,jakości życia”.

${ }^{8}$ Jan Paweł II, Redemptor hominis, w: Jan Paweł II Redemptor hominis, Tekst i komentarze, Lublin 1984, 10. 


\section{Ewangelia godności człowieka}

Syntetycznie ujmując wskaźniki godności człowieka, można je określić jako zdolność poznania, wolność i umiejętność kierowania się preferencją wartości. „Osoba ludzka uczestniczy w świetle i mocy Ducha Bożego. Dzięki rozumowi jest zdolna do rozumienia porządku rzeczy ustanowionego przez Stwórcę. Dzięki swojej woli jest zdolna kierować się sama z siebie do swojego prawdziwego dobra. Swoją doskonałość znajduje w «poszukiwaniu i umiłowaniu tego, co prawdziwe i dobre»" ${ }^{9}$. Warto dopełnić tego obrazu przywołaniem faktu, że wyjątkowa wartość dotyczy integralności człowieczeństwa. W dobie współczesnych zagrożeń trzeba zatem wyartykułować wartość cielesności oraz dopowiedzieć o zdolności człowieka do uczestnictwa we wspólnocie.

Dzieło stworzenia objawia nie tylko sam fakt zaistnienia człowieka, ale odsłania jego tajemnicę. Wskazuje, że człowiek jest powołany do panowania nad Ziemią, które ma się odbywać nie na zasadzie wyniszczającej eksploatacji, ale pewnego rodzaju twórczej kontynuacji dzieła stwórczego. Objawia także, że człowiek jest obrazem Boga również ze względu na wzajemne odniesienie mężczyzny i kobiety, ich wzajemna komunia osób stanowi pewnego rodzaju podobieństwo do jedności trzech Osób Trójcy Świętej. W tej manifestacji człowieczeństwa zawiera się prawda o istnieniu człowieka jako podmiotu zdolnego do poznania umysłowego oraz wolności.

Zdolność poznania umysłowego odróżnia człowieka zasadniczo od całego świata zwierzęcego, gdzie zdolność poznawcza ogranicza się do zmysłów. Poznanie umysłowe czyni człowieka zdolnym do sądzenia, do rozróżniania pomiędzy prawdą a nieprawdą, otwierając przed nim całą sferę nauki, myślenia krytycznego i metodycznego dociekania prawdy o rzeczywistości. Człowiek zostaje od wewnątrz związany zasadniczą refleksją do prawdy, która stanowi o transcendentnym charakterze ludzkiego podmiotu. Poznanie prawdy przenika całą sferę odniesienia człowieka do świata, jak też do innych ludzi, wyznaczając same zręby ludzkiej kultury ${ }^{10}$.

Elementarna prawda o człowieku staje się dla niego samego możliwa do odkrycia i przyjęcia dzięki właśnie władzom poznawczym. Odkrycie tej prawdy jest rodzajem autoinformacji, która od chwili objawienia jej sobie własnym aktem poznania przestaje być informacją neutralną. Staje się raczej rodzajem moralnego autoimperatywu. Domaga się on wierności rozpoznanej prawdzie.

\footnotetext{
${ }^{9}$ KKK 1704.

${ }^{10}$ Jan Paweł II, Człowiek -obraz Boży jako podmiot poznania $i$ wolności, w: Jan Paweł II, Co to znaczy wierzyć?, Warszawa 1988, s. 166.
} 
Świadome jej zanegowanie oznacza nie tylko sprzeniewierzenie się prawdzie, ale ostatecznie jest sprzeniewierzeniem się sobie, utratą bycia sobą ${ }^{11}$.

Refleksja nad zdolnością poznania w człowieku prowadzi zatem do wniosku, że „właściwa człowiekowi godność, ta, która mu jest dana i równocześnie zadana, wiąże się ściśle z odniesieniem do prawdy. Myślenie w prawdzie i życie w prawdzie stanowi o tej godności" ${ }^{12}$.

Temat poznania jako możliwości (zdolności) osoby ludzkiej zostaje dopełniony wielością wolności. Obie wielkości w sposób bezpośredni wynikają z biblijnego przedstawienia człowieka jako obrazu Bożego. Święty Jan Paweł II stwierdza:

W organicznym związku z poznaniem umysłowym oraz relacją do prawdy pozostaje wolność ludzkiej woli, która jest do wewnątrz związana relacją do dobra. Czyny ludzkie noszą na sobie znamię samodzielnej decyzji (chcenia) oraz wyboru. Na tym gruncie rodzi się cała sfera moralności. Człowiek bowiem jest zdolny wybierać pomiędzy dobrem a złem, w czym pomaga mu głos sumienia, które nakłania do dobra, a przestrzega przed złem ${ }^{13}$.

Wymienione komponenty godności osoby jako obrazu Bożego, a mianowicie poznanie prawdy i wolność decydowania, pozostają do siebie w określonej relacji. Jest to relacja dynamiczna i dramatyczna zarazem. Tworzy stosunek wolności jako samozależności człowieka od jego zależności od prawdy.

Poznanie prawdy o własnej godności mocą własnego poznania jest rodzajem samozwiązania się tą prawdą. Jest to jednak rodzaj „uzależnienia” mocą własnych decyzji i własnych aktów. Człowiek zostaje poniekąd zobowiązany do niesprzeniewierzenia się prawdzie, gdyż byłoby to sprzeniewierzenie się nie tylko abstrakcyjnej treści, ale samemu sobie. Absolutyzacja wolności wyboru, która przejawiłaby się w rezygnacji z prawdy, w akcie zakłamania byłaby w swej istocie rodzajem radykalnego samozniewolenia. Można więc stwierdzić: „Wolność człowieka staje się, innymi słowy, ludzką wolnością, która buduje człowieka w człowieku tylko, jeśli jest wolnością poddającą się prawdzie, dokładniej wolnością oddającą się w jej służbę. Jedynie taka wolność wyzwala człowieka w człowieku"14.

W relacji rozpoznawanej prawdy i podejmującej decyzje wolności zasadniczą rolę odgrywa sumienie. Wydarzenie stwórcze w całej swojej pełni znaczenia teologicznego jest momentem tworzącym osobę jako podmiot etyczny.

${ }^{11}$ Por. T. Styczeń, Być soba to przekraczać siebie. O antropologii Karola Wojtyły, w: tenże, Solidarność wyzwala, Lublin 1993, s. 87-88.

${ }^{12}$ K. Wojtyła, Znak sprzeciwu, Paris 1980, s. 115.

${ }^{13}$ Jan Paweł II, Człowiek - obraz..., dz. cyt., s. 166-167.

${ }^{14}$ T. Styczeń, Być sobq..., dz. cyt., s. 98. 
Określeniem tego jest miara odpowiedzialności osoby ludzkiej. Odpowiedzialność jest istotnym przejawem sumienia, a jednocześnie jest przejawem wartości. Wynika to z faktu, że przez ustanowienie osoby jako podmiotu etycznego ustanowiona zostaje osoba jako wartość. Stworzenie jest także ustanowieniem wartości, w konsekwencji godność sumienia wyznacza godność osoby. Sobór wypowiada się na ten temat w sposób następujący:

W głębi sumienia człowiek odkrywa prawo, którego sam sobie nie nakłada, lecz któremu winien być posłuszny i którego głos wzywający go zawsze tam, gdzie potrzeba, do miłowania i czynienia dobra, a unikania zła, rozbrzmiewa w sercu nakazem: czyń to, tamtego unikaj. Człowiek bowiem ma w swym sercu wypisane przez Boga prawo, wobec którego posłuszeństwo stanowi o jego godności i według którego będzie sądzony. Sumienie jest najtajniejszym ośrodkiem i sanktuarium człowieka, gdzie przebywa on sam z Bogiem, którego głos w jego wnętrzu rozbrzmiewa (KDK 16).

W sumieniu i dzięki niemu człowiek odkrywa swój własny wymiar etyczny. Jest tak dlatego, że jego sumienie jest wyrazem wymagań moralnych. Nie należy ich jednak traktować jako czegoś heteronomicznego w stosunku do człowieka. Te wymagania moralne (wartość lub prawo) to sama rzeczywistość człowieka jako człowieka. Sumienie w tym kontekście jest tą samą ludzką rzeczywistością, która przybiera kształt słowa (zobowiązującego). Mówienie o prawie i sumieniu jest rozprawianiem o dwóch aspektach korelatywnych i nierozdzielnych jednej i tej samej rzeczywistości. Oznacza to, że człowiek jest sumieniem i prawem w swej konstytucji. Człowiek jest sumieniem, które jest prawem, i jest prawem, które jest sumieniem. Sumienie jest głosem prawa, a prawo jest rzeczywistością sumienia.

Można zatem powiedzieć, że sumienie i prawo to człowiek rozważany jako podmiot etyczny. Odkrycie tego wymiaru etycznego jest odkryciem człowieka jako zadania, którym jest on sam i do którego jest zobowiązany. Stąd można wysunąć wniosek-postulat, by człowiek był wierny i posłuszny swemu sumieniu, które objawia osobie ludzkiej obowiązek życia, godność życia i prawo życia.

W kontekście stworzenia jaśniejsze staje się stwierdzenie, że prawo moralne lub wartość człowieka (prawda jego bytu) są jedynie odkrywane przez człowieka, a nie przez niego tworzone. Prawo i prawda są dane człowiekowi, i to tak, że winien on być im posłuszny. Jednocześnie człowiek odkrywa prawo tak, jak odkrywa się to, ,jak żyć”.

Nie można mówić jedynie o osobie jako podmiocie działania i uwarunkowaniach tych aktów, ale trzeba widzieć głęboką tożsamość, identyfikację osoby z jej aktami. Inaczej mówiąc, osoba uobecnia i aktualizuje wartości w takiej mierze, w jakiej sama jest wartością. 
W tym miejscu bardzo wyraźnie można dostrzec różnicę prezentowanego ujęcia z koncepcją Maxa Schelera, którego aksjologia wyróżniała wartość jako wartość samą w sobie. Myśl aksjologiczna w teologii moralnej opowiada się za wyraźnym powiązaniem wartości z osobą. Są one przeżywane przez osobę i wpływają na jej rozwój.

Istnieje bardzo wiele pojęć i koncepcji wartości, a w związku z tą niejednoznacznością pojawia się duża trudność porozumienia w dziedzinie aksjologii. $\mathrm{Z}$ drugiej strony samo pojęcie wartości, bez analizy jego znaczenia, funkcjonuje w języku potocznym, etycznym, publicystycznym, a nawet politycznym. Istnieją tendencje subiektywizowania bądź obiektywizowania wartości. Są także trendy do utożsamiania jej z dobrem jako takim, a przez to pozbawiania jej racji bytu. Pojawia się zatem potrzeba opowiedzenia się za jakąś konkretną koncepcją wartości, by uniknąć nieporozumień. Wydaje się, że jedną z najbardziej adekwatnych prób jest koncepcja Dietricha von Hildebranda, u której podstaw leży najogólniejsze ze stosowanych pojęć, a mianowicie - „ważność” (Bedutsamkeit). Jest ona takim momentem doświadczanym przez człowieka, który wywołuje reakcję uczuciową lub też motywuje wolę osoby. Ma ona charakter zawsze pozytywny lub negatywny, a przez to odpowiedni czyni przedmiot dobrem lub złem. W ramach ważności rozróżnić można trzy zasadnicze kategorie:

- ważność wewnętrzną wartości (np. szlachetnego czynu),

- ważność tego, co subiektywnie zadowalające (np. komplementu),

- ważność, jaka znamionuje obiektywne dobro dla osoby.

To właśnie obiektywne dobro dla osoby jest miarą moralnej wartości czynu. Hildebrand wylicza kilka kategorii tego obiektywnego dobra:

1) bycie nosicielem wartości,

2) wartości uszczęśliwiające aż do najwyższej, czyli zbawienia człowieka,

3) wartości powszechnie uważane za podstawowe i elementarne w ludzkiej egzystencji,

4) dobra uprzyjemniające.

Wartości nie pozostają w neutralnym stosunku do osoby ludzkiej. Przeżywane przez człowieka domagają się odpowiedzi. Dokonuje się ona w wolnym, osobowym centrum tendencji tak pozytywnych, jak i negatywnych. Przy tym, realizacja najwyższego dobra dla osoby (odpowiedź na to dobro) nie jest tylko fakultatywna. Jest ściśle moralnie zobowiązująca. Podobnym charakterem powinnościowym naznaczone są wartości moralne. Dobra niższej rangi nie mają już tej mocy wezwania obligatoryjnego. 
Wśród odpowiedzi na wartość szczególną uwagę należy poświęcić takiemu ustosunkowaniu się, które domaga się wchodzenia w duchowy kontakt $\mathrm{z}$ innymi osobami. Dążenie do najściślejszego zjednoczenia z drugimi jest możliwe pod warunkiem tworzenia z własnego życia daru dla innych. Wówczas zjednoczenie $\mathrm{z}$ innymi osobami staje się nowym wymiarem kontaktu $\mathrm{z}$ wartościami, a zarazem wyrażaniem wspólnoty miłości. „Charakterystyczne dla miłości dawanie samego siebie, nowe i najgłębsze zainteresowanie się wewnętrzną wartością drugiego, przywiązanie do jedności duchowej z tą osobą wszystko to sprawia, że osoba dostępuje najpełniejszego udziału w wartościach, jak też sama siebie najpełniej i najwyraźniej objawia w swej istocie"15.

Ten aspekt osoby w świecie wartości wskazuje najpierw na powinność afirmowania osoby przez osobę, a ponadto na właściwą drogę samorealizacji człowieka w wyłącznej relacji miłości: ja-ty. Swoją miłość, jako szczytową odpowiedź osoby na wartość człowiek przedstawia całym sobą. W tej wypowiedzi ludzkiej osoby istotną rolę odgrywa język ciała.

Prawda o godności człowieka jako obrazu Bożego, odnowionego przez czyn zbawczy Chrystusa, dotyczy całości człowieczeństwa, to znaczy osoby, która jest zarazem jednością i dwoistością (duszy i ciała).

Chociaż filozoficzna terminologia, użyta dla wyrażenia jedności i złożoności (dwoistości) człowieka, bywa nieraz przedmiotem krytyki, to jednakże nie ulega wątpliwości, że sama nauka o jedności ludzkiej osoby i równocześnie dwoistości duchowocielesnej człowieka jest w pełni zakorzeniona zarówno w Piśmie świętym, jak i w Tradycji. A chociaż często wyraża się przeświadczenie, że człowiek jest „obrazem Boga” tylko dzięki swej duszy, to w parze z tym idzie przekonanie, że również i ciało na swój sposób uczestniczy w godności „obrazu Bożego”, tak jak uczestniczy w godności osoby ${ }^{16}$.

Ciało ludzkie należy do rzeczywistości, których poznanie stanowi pewnego rodzaju paradoks, jest $\mathrm{z}$ jednej strony codziennie doświadczane jako wprost to, co jest człowiekiem, a $\mathrm{z}$ drugiej strony pozostaje w dużej mierze tajemnicą.

Fundamentalnym i centralnym elementem tej tajemnicy jest wydarzenie „pełni czasów”, które wyraża się w sformułowaniu: Bóg stał się Ciałem. Od tej chwili mówienie o ludzkim ciele staje się, w jakimś sensie, doświadczaniem samego Boga. Ludzkie ciało Jezusa było ciałem zwyczajnym, nienaznaczonym żadną nadzwyczajnością, obdarzone od urodzenia płcią. Charakter wy-

${ }^{15}$ P. Góralczyk, Możliwość uwzględnienia założeń systemowych etyki Dietricha von Hildebranda w teologii moralnej, Poznań 1989, s. 153; por. D. von Hildebrand, Trzy główne formy udziału człowieka w wartościach, w: tenże, Serce, Poznań 1985, s. 177n.

${ }^{16}$ Jan Paweł II, Co to znaczy wierzyć?, Warszawa 1988, s. 163-164. 
różniający płci ludzkiej, zaznaczony w cielesności, jest już dany człowiekowi od samego początku, od stworzenia.

Tajemnica wcielenia pozwala stwierdzić dobitnie: „Ciało ludzkie nie jest abstrakcją. Jest wielką wypadkową licznych uwarunkowań historycznych, naturalnych, ludzkich i nadprzyrodzonych. A wśród nich narodowość i rasa odgrywają istotną rolę"17.

Cielesność ma zatem dla teologii moralnej znaczenie specyfikujące i konkretyzujące podmiot działania moralnego. Poprzez nią człowiek wchodzi w historię i wpisuje swoje dzieje w Ziemię. Pozwala na usytuowanie człowieka w konkretnych okolicznościach, co ma wielkie znaczenie dla oceny działania moralnego.

Wcielenie Słowa Bożego dowodzi, że niesłuszne jest deprecjonowanie wartości ciała, że nie można poniżać ciała z racji płciowości. Ciało pełni, jako forma duszy, określone funkcje w strukturze człowieczeństwa. Przede wszystkim chroni duszę, chroni to, co jest w człowieku najgłębsze i najbardziej wewnętrzne, owo centrum ludzkiej jaźni: sumienie i możność wchodzenia $\mathrm{w}$ dialog.

Ciało ponadto chroni duszę przed złem. Zabezpiecza człowieka przed uległością sugestiom Szatana, ojca kłamstwa. Szatan pozostaje duchem, a kiedy się wciela, czyni to w sposób negatywny lub negujący. Ciało odgrywa wreszcie bardzo istotną rolę w reprodukcji życia. Zgodnie z nauką św. Pawła trzeba najpierw spoglądać na całość ludzkiej cielesności, niezbędność wszystkich członków dla nich samych i wzajemnie dla siebie (Por. 1 Kor 12,18-21). Znamienne jest rozmieszczenie różnych członków ciała ludzkiego. Na szczególną uwagę zasługuje zdumiewające zespolenie tego, co podlejsze w ludzkim ciele, $\mathrm{z}$ tym, co jest wzniosłe (organy moczowe zespalają się w organizmie $\mathrm{z}$ organami płciowymi wyposażonymi w zdolności reprodukcji gatunku). Komentując ten układ, Scheler zauważa:

Ta właśnie budowa ma niesłychane znaczenie w wykluczaniu, na ile to możliwe, tych wszystkich aktów płciowych, które z tego tylko powodu, że brak im wstydu, mogłyby zrodzić jedynie byty obciążone wartościami negatywnymi. Z racji samej swej budowy natura stawia $\mathrm{w}$ ten sposób alternatywę: wstyd lub niesmak, wykluczając wszelką drogę pośrednią, to wszystko, co byłoby zwykłym szukaniem rozkoszy ${ }^{18}$.

Ciało objawia zatem wstyd i demaskuje go, a wstyd stanowi jedną z ważniejszych konstrukcji i funkcji sumienia moralnego w ogólności.

\footnotetext{
${ }^{17}$ M. Sales, Misterium ciata ludzkiego, „Communio” 2(1982) nr 2 (8), s. 85.

${ }^{18}$ M. Scheler, La pudeur, Paris 1952, s. 129-130.
} 
Związek ciała i duszy, w perspektywie moralnej wskazuje na charakter uzależnienia duszy, ludzkiego ducha lub serca od ciala. Wygląda to tak, jakby Bóg wraz z cielesnością dał człowiekowi przewróconą hierarchię wartości. Jednakże, degradacja ciała ludzkiego w wyniku choroby, starzenia się, a ostatecznie śmierci, staje się szczególnym doznaniem dla tych, którzy odrzucają prawdę zmartwychwstania. Staje się pewnego rodzaju dramatycznym pytaniem o sens ludzkiego wysiłku w poczynaniach. Jest, z drugiej strony, otwarciem ludzkiej nadziei zmartwychwstania, które znajduje wyraźne dopełnienie w prawdzie wiary (por. Mt 22,23-33).

Osoba ludzka wskazuje na dwie jakby dychotomiczne rzeczywistości. $\mathrm{Z}$ jednej strony codzienne doświadczenie ukazuje zdolność komunikowania się międzyosobowego, z drugiej każdy człowiek jest przeświadczony o jednostkowości swojego powołania, pewnej indywidualności i niepowtarzalności. Można zatem mówić o podwójnym wymiarze osoby ludzkiej: wspólnotowym (społecznym, dialogowym, relacyjnym) i wsobnym (jednostkowym, indywidualnym).

Zdolność komunikacji wskazuje na pewnego rodzaju zgodę, synchronizację między poszczególnymi indywidualnymi osobami. Ta zgoda czy zjednoczenie przebiega $\mathrm{w}$ różnych obszarach człowieczeństwa: w sferze poznania, woli i miłości. Możliwość takiej synchronizacji zakłada pewną wspólną podstawę, podstawową strukturę wspólną. Głębia dokonującej się wymiany, komunikacji wskazuje także na to, że taka struktura nie może być czymś powierzchniowym, lecz ma charakter podstawowy, jest osobą w jej aspekcie fundamentalnym.

Omawiana rzeczywistość duchowa i biologiczna, w której każda osoba uczestniczy w sposób sobie właściwy, zróżnicowany, indywidualny, nosi nazwę natury ludzkiej ${ }^{19}$. Trzeba zauważyć bardzo istotną różnicę między rozumieniem natury u bytów poniżej ludzkich (infraludzkich) a naturą człowieka. $\mathrm{O}$ ile w tamtych pierwszych przypadkach natura jest czymś zamkniętym $\mathrm{w}$ tym sensie, że istota i działanie tych bytów są związane $\mathrm{z}$ określonym środowiskiem (ograniczonym), o tyle w wypadku człowieka natura jest otwarta. Oznacza to, że dzięki absolutnej transcendencji poznania i woli natura ludzka przekracza jednostkowość i zwraca się ku rzeczywistości samej w sobie, a tym samym ostatecznie ku Bogu. Dzięki temu natura może zobiektywizować samą siebie, uczynić przedmiotem własnego działania, wejść w relację dialogu z Bogiem jako fundamentem całej rzeczywistości. Ona więc nadaje charakter osobowy człowiekowi. Dlatego nie można traktować jej wyłącznie w kategoriach czysto biologicznych, nie można też zapominać o jej otwarto-

${ }^{19} \mathrm{Na}$ temat natury ludzkiej por. szerzej: M.A. Krąpiec, Ja człowiek, Lublin $1986^{2}$, zwłaszcza s. 364-368. 
ści, czyniąc z niej jedną i sztywną rzeczywistość dotyczącą w całości każdego człowieka $^{20}$.

Z kolei na podłożu powszechności budowanej na wspólnej naturze może istnieć i faktycznie istnieje jako sprawa zasadnicza i pierwsza jednostkowość i indywidualność poszczególnych osób. Należy jeszcze zauważyć, że natura ludzka jako rzeczywistość powszechna, wspólna i właściwa każdej indywidualnej osobie stanowi warunek moralności ogólnoludzkiej, tzn. ważnej dla wszystkich ludzi ${ }^{21}$.

Mówiąc o wymiarze dialogalnym człowieka (w aspekcie moralnym), można wyróżnić jego najważniejsze trzy elementy:

1 - osoba jest zdolna do rozwoju i przekraczania samej siebie. Metafizycznopsychologiczną podstawą tej prawdy jest przekonanie, że osoba jest kluczem do tajemnicy bytu. Osoba ma swój byt, ale także możność bytu, a w konsekwencji to, co można określić jako powinność bytu. To znaczy osoba rozumie, kim jest, kim jeszcze nie jest i kim może się stać. Oczywiście, takie rozpoznanie osoby może być błędne, ale nie oznacza to przekreślenia definitywnego dążenia do rozwoju.

Można przy tym zauważyć, że natura ludzka, która ma wrodzoną plastyczność, rozwija się w biegu historii w licznych formach kultur i cywilizacji. Służą one zaspokajaniu potrzeb eksploatacyjnych ludzkiej natury. Dowodem tego są współczesne zjawiska uspołecznienia w wymiarze międzynarodowym, wspólnoty światowej i świadomości międzynarodowej. Z pojęciem historii wiąże się pojęcie postępu, czyli rozwoju i posuwania się ku formie pełniejszego realizowania idei człowieka ${ }^{22}$.

2 - osoba ma zdolność do daru z siebie. Jest to konsekwencja rozpoznania w świecie ,ja” i tego, co jest „nie-ja”. To odrębne „nie-ja” odkrywa osoba (,ja”) w rzeczach, innych osobach (to odkrycie staje się rozpoznaniem „ty”) i w Bogu jako Istocie i Osobie Najwyższej. Poznanie nie-ja w rzeczach idzie w kierunku świadomości, że to nie osoba istnieje dla rzeczy, ale one istnieją dla osoby. Rozpoznanie w osobach wiąże się z oddawaniem się im na płaszczyźnie partnerskiej, ale także przez zrozumienie, że inny człowiek jako osoba nie może zostać urzeczowiony ani użyty instrumentalnie. Wreszcie odkrycie „nie-ja” w Bogu dokonuje się przez przyjęcie Go jako najwyższej wartości oraz przez zrozumienie, uznanie, że Boży plan dotyczący świata i człowieka jest nieskończenie mądry i pełen miłości. W konsekwencji takiego uznania

${ }^{20}$ Por. K. Rahner, H. Vorgrimmler, Natura, w: K. Rahner, H. Vorgrimmler, Mały stownik teologiczny, 262-263.

${ }^{21}$ Por. J.M. Aubert, Jak żyć po chrześcijańsku w XX wieku, Warszawa 1986, s. 110-111.

${ }^{22}$ Por. J.M. Aubert, Jak żyć..., dz. cyt., s. 111-113. 
powinna pojawić się decyzja podporządkowania Bożemu zamysłowi własnej wizji życia. W tym kontekście dar z siebie staje się samookreśleniem siebie na rzecz drugiego „ty” („Ty”).

3 - osoba ma zdolność do asymilacji. Poprzednia struktura dialogowa osoby domaga się istotnego dopełnienia zdolności przyjęcia czegoś od innego. Taka zdolność przyjęcia wiąże się z umiejętnością interioryzacji, czyli przyswojenia tego, co jest darowaną częścią świata, osoby, w specyficznym sensie także Boga.

Wymienione pokrótce komponenty godności osobowej mają ogromne znaczenie we współczesnych sporach o życie. Pozwalają najpierw i przede wszystkim ustalić jako warunek rozwoju człowieka wewnętrzną autodeterminację - samozwiązanie się człowieka poznaną prawdą o swojej godności. W takiej perspektywie niegodziwy staje się jakikolwiek akt zamachu na ludzkie życie - jest on bowiem ugodzeniem w prawdę o wartości osoby ludzkiej. Wskazana koncepcja godności traktuje człowieka integralnie jako „wcielonego ducha” czy „uduchowione ciało”, co kategorycznie przeczy możliwości zamachów na człowieka zredukowanego do wymiaru biologicznego (niszczenie płodów, tkanek płodowych, zarodków nadliczbowych nie jest w tej perspektywie niszczeniem substancji biologicznej, ale niszczeniem życia ludzkiego). Wreszcie wymiar dialogalny osoby ludzkiej pozwala dostrzec, że tak jak wektorem samorealizacji człowieka jest powinność bycia darem dla drugiego, tak wyrazem autodestrukcji staje się każdy akt zawłaszczania drugiej osoby w imię różnorako realizowanego egoistycznego indywidualizmu.

Konsekwencją wnikliwej analizy godności osoby ludzkiej może być tylko jedno stwierdzenie: „Życie zawsze jest dobrem. Człowiek jest powołany, aby zrozumieć głęboką motywację tego intuicyjnego przeświadczenia, które jest też faktem poznawalnym doświadczalnie" (EV 34).

\section{Ewangelia życia}

Dobroć, wartość ludzkiego życia staje się w pełni czytelna, gdy życie ludzkie zostaje usytuowane w perspektywie celu ostatecznego, który jest konsekwencją struktury osobowej człowieka. Osobowy charakter człowieka, jego racjonalność i możliwości wynikające $\mathrm{z}$ wolnej woli, siła transcendowania, możliwość stawiania (rozpoznawania) celu i jego realizacji wszystko to wyróżnia zdecydowanie człowieka spośród innych stworzeń. Nakłada też obowiązek formowania własnych postaw życiowych, adekwatnych do potencjału osobowego. Jest też znamieniem dojrzałości, gdyż człowiek dojrzały reflek- 
tuje nad sensem własnego życia, nad celem swoich wysiłków i zamierzeń. Dla człowieka religijnego sfera tego celu i jego autorstwo pozostają w ścisłym i bezpośrednim związku z Bogiem. Czytelne stają się wówczas słowa św. Pawła: „Albowiem tych, których od wieków poznał, tych też przeznaczył na to, by się stali na wzór obrazu Jego Syna [...] Tych zaś, których przeznaczył, tych też powołał, a których powołał, tych też usprawiedliwił, obdarzył chwałą" (Rz 8,29-30).

Zarówno Pismo Święte, Tradycja Kościoła, jak i współczesne nauczanie Magisterium nie pozostawiają wątpliwości co do tego, że kresem ludzkiego przeznaczenia jest sam Bóg i wspólnota osobowa z Nim. „Bóg bowiem stworzył nas, byśmy Go poznawali, służyli $\mathrm{Mu}$, miłowali Go, i w ten sposób doszli do raju. Szczęście czyni nas «uczestnikami Boskiej natury» (2 P 1,4) i życia wiecznego [por. J 17,3]. Wraz z nim człowiek wchodzi do chwały Chrystusa [por. Rz 8,18] i do radości życia trynitarnego"23. Charakter wielu wypowiedzi biblijnych jest przy tym tak dobitny, że mają one znamię świadectwa.

Słownictwo biblijne, a za nim terminologia innych świadectw zwykło określać rzeczywistość trwałej wspólnoty z Bogiem w kategoriach „widzenia” (por. 1 Kor 13,12; 1 J 3,2; Ap 7,9-16; 22,4). Jednak z danych objawienia wynika jednoznacznie, że przeznaczenie człowieka do bezpośredniego oglądania Boga należy do sfery nadprzyrodzonej, to jest do poziomu, do którego tylko sam Bóg może wynieść człowieka. Tak więc treść przeznaczenia jest w jak najbardziej ścisłym tego słowa znaczeniu nadprzyrodzona ${ }^{24}$.

Obiektywny finalizm ludzkiego życia w postaci trwałej wspólnoty z Bogiem nie wyczerpuje misterium przeznaczenia. Pozostaje przecież jeszcze aspekt subiektywny podmiotowy. Jest nim przede wszystkim miłość do Boga i udział w Jego miłości. Oznacza to, że chrześcijańska egzystencja jest ukierunkowana na miłość, która jest wartością najistotniejszą. Dodatkowo, przy tym zetknięciu się ludzkiej miłości z Bogiem, który jest Miłością, dokonuje się całkowite wyniesienie ludzkiego bytu. Nie oznacza to zniweczenia naturalnej struktury bytowej osoby, ale nadanie zupełnie nowej relacji do rzeczywistości.

Człowiek, osiągnąwszy kres swego przeznaczenia, staje się posiadaczem tego, czego domaga się cała jego istota. Odpadają odeń wszelkie doczesne pragnienia, a udziałem jego staje się pełnia osobowa, spokój i uciszenie wewnętrzne. Ten spoczynek w Bogu, rodzący radość i stan pełnego nasycenia, teologia określa posługując się terminem św. Tomasza jako szczęśliwość zbawczą (beatitudo). Objawienie wykazuje, że w planach Bożych jest ona zamierzona jako stan ostateczny ${ }^{25}$.

\footnotetext{
${ }^{23}$ KKK 1721.

24 Por. S. Rosik, Wezwanie do ludzkiej petni, w: tenże, Wezwania, s. 64-66.

25 S. Rosik, Wezwanie..., dz. cyt., s. 67. Por. STh III q.1 a.8 ad pb.; q.3 a.1.
} 
Ostateczna, to znaczy eschatyczna finalność przeznaczenia winna jednak być zapoczątkowana w egzystencji historycznej i ziemskiej. W takim właśnie sensie historycznym oraz społecznym i kulturowym przybiera wówczas postać realizacji konkretnych zadań życiowych. Realizacja ta określana jest mianem „powołania" 26 . Jedną z najtrudniejszych, ale zarazem bezcennych form tego powołania może być powołanie do uczestnictwa w cierpieniu Chrystusa ${ }^{27}$.

Papieska wizja kultury życia jako radykalnej i bezwzględnej opozycji względem szerzonej kultury śmierci w samym swoim rdzeniu zawiera proklamację „Ewangelii miłości Boga do człowieka”. Pozwala to na dobitne dostrzeżenie szczególnej jakości wyróżniającej człowieka w świecie istot żywych - człowiek zawdzięcza życie Bogu w sposób szczególny, gdyż „tylko jego stworzenie zostaje przedstawione jako owoc specjalnej decyzji Boga" (EV 34).

Perspektywa teologiczna pokazuje z jednej strony wymiar bezinteresownej miłości Boga, ale także umożliwia ukazanie życia jako daru miłości. Konsekwencje tej perspektywy wskazują, że życie nie jest autonomicznym dominium człowieka oraz że należy dostrzegać w ramach integralnej i adekwatnej antropologii integralność życia - fizycznego, duchowego, wiecznego.

Święty Jan Paweł II ze szczególną predylekcją podjął (nie tylko w encyklice, ale w świadectwie swojego życia) kontemplację ,wypełnienia i pełnego objawienia całej Ewangelii życia" - w Krzyżu Chrystusa:

Patrząc na „widowisko” krzyża (Łk 23,48), możemy dostrzec w tym chwalebnym drzewie wypełnienie i pełne objawienie całej Ewangelii życia.

Wczesnym popołudniem w Wielki Piątek ,mrok ogarnął całą ziemię [...]. Słońce się zaćmiło i zasłona przybytku rozdarła się przez środek" (Łk 23,44-45). Jest to obraz wielkiego kosmicznego wstrząsu i nadludzkiego zmagania między siłami dobra i siłami zła, między życiem i śmiercią. I my znajdujemy się dziś w samym centrum dramatycznej walki między „kulturą śmierci” i „kulturą życia”. Ale blask Krzyża nie zostaje przesłonięty przez ten mrok - przeciwnie, na jego tle Krzyż jaśnieje jeszcze mocniej i wyraźniej, jawi się jako centrum, sens i cel całej historii i każdego ludzkiego życia.

Jezus zostaje przybity do krzyża i wywyższony nad ziemię. Przeżywa chwile swej największej „niemocy”, a Jego życie wydaje się całkowicie zdane na szyderstwa przeciwników i przemoc oprawców: drwią z Niego, wyśmiewają Go i znieważają (por. Mk 15,24-36). Ale właśnie w obliczu tego wszystkiego, „widząc, -79 .

${ }^{26} \mathrm{Na}$ temat powołania jako implikacji przeznaczenia por. S. Rosik, Wezwanie..., dz. cyt., s. 68-

${ }^{27}$ Por. J. Salij, Pytanie o sens cierpienia, w: Miłość i cierpienie. Misterium Boga i nadzieja człowieka, red. J. Malski i I. Rutkowska, Głogów 2010, s. 51-64; S. Palumbieri, Cierpienie i sens. Między rozumem i wiara, w: Miłość i cierpienie, dz. cyt., s. 65-95; P. Bortkiewicz, Obecność Chrystusa w cierpieniu, w: Miłość i cierpienie, s. 96-106. 
że w ten sposób oddał ducha”, rzymski setnik woła: „Prawdziwie, ten człowiek był Synem Bożym” (Mk 15,39). Tak więc tożsamość Syna Bożego objawia się w chwili Jego skrajnej słabości: na Krzyżu ukazuje się Jego chwała! (EV 50).

\section{Życie jako zadanie}

Teologia stworzenia i chrystologia wskazują dobitnie na najgłębszą genezę życia - pochodzi ono od Boga i dokonuje się (powinno być przeżywane) dla Boga. Ta rytmika daru życia („od” - „dla”) stanowi jego spełnienie i najpełniejszą realizację. Faktycznie jest na miarę godności człowieka jako osoby, a zarazem w opozycji do funkcjonalistycznej wizji człowieka, zakwestionowanie tej perspektywy życia jest negacją godności osoby.

W tej właśnie perspektywie, w której życie jest produktem o określonej (niskiej) jakości, a nie wartości, jest uznaniowo obdarzane „godnością”, pojawia się powinność głoszenia Ewangelii życia. Papież w swojej encyklice wskazuje przy tym faktycznie na potrójną powinność związaną z proklamacją Ewangelii życia: „ "Oznajmiamy wam, cośmy ujrzeli i usłyszeli» (1 J 1,3): głosić Ewangelię życia” (EV 80), „«Dziękuję Ci, że mnie stworzyłeś tak cudownie» (Ps 139[138],14): wysławiać Ewangelię życia” (EV 83), „«Jaki z tego pożytek, bracia moi, skoro ktoś będzie utrzymywał, że wierzy, a nie będzie spełniał uczynków?» (Jk 2,14): służyć Ewangelii życia” (EV 87)

Wydaje się, że wyrazem głoszenia Ewangelii życia we współczesnym świecie staje się podkreślenie racji antropologicznych. Pozwalają one na to, by w sporach światopoglądowych i ideowych uzasadnić i umocnić szacunek dla życia w świetle rozumu i doświadczenia. Mówiąc o racjach antropologicznych, trzeba mieć przy tym na uwadze złożoność współczesnych koncepcji antropologicznych, także wewnątrz samego chrześcijaństwa i katolicyzmu. Dlatego należy jednoznacznie promować ,,antropologię adekwatną”, która nie godzi się ani na ucieczkę w biblicyzm, ani na oddanie pola socjobiologom. Taka antropologia winna być wsparta rzetelną hermeneutyką, której wyrazem jest kompetentny opis egzystencji człowieka, zgodnie z objawieniem Bożym.

Szczególne miejsce w tym przesłaniu zajmuje teologia ciała jako konkretyzacja antropologii, w której kluczem jest rozumienie człowieka stworzonego na obraz i podobieństwo Boże. Pozwala ona dostrzec, że cielesność człowieka to coś znacznie więcej niż materialność ludzkiego ciała. Jest ona także wyrazem samostanowienia człowieka w świecie, czasie i historii. Przejawia się w trudzie istnienia, mimo lęku przed śmiercią, winą i bezsensem. Ostatecznie, jest miejscem tęsknoty za Bogiem-Miłością.

Zadanie wysławiania Ewangelii życia najpierw wskazuje na to, że jego podstawą jest uczestnictwo człowieka w kapłańskiej funkcji Pana Jezusa. To 
zaś domaga się od człowieka wierzącego ofiarowania siebie i swoich uczynków Bogu, składania ofiary eucharystycznej w świecie poświęconym. Wypełnianie funkcji kapłańskiej i przeżycie zachwytu wobec życia oraz odniesienie tego doświadczenia do Boga jest w tej perspektywie fundamentalnie ważne. Tylko bowiem ta koniunkcja może doprowadzić do konsekwentnej służby życiu.

Zadziwienie cudem życia przemienia się w postawę dziękczynienia, a stąd już tylko prosta droga prowadzi do wysławiania życia - w życiu sakramentalnym. Warto w tym miejscu wspomnieć o istnieniu tzw. „sakramentów naturalnych" w najszerszym sensie tego słowa, jakby ,prasakramentów”. Odczytywane są one szczególnie w czterech momentach ludzkiej egzystencji: narodzeniu, śmierci, posiłku i wspólnocie seksualnej. Wreszcie podejmowane w życiu i życiem zadanie służenia Ewangelii życia domaga się przede wszystkim świadectwa osobistego. Jego wyrazem jest i powinna być troska o nienarodzonych, cierpiących i ubogich. Także osobiste świadectwo realizacji np. własnej płciowości ma fundamentalne znaczenie w wywyższaniu „«doskonałego» człowieczeństwa i prawdziwego «życia» człowieka"28.

„Służyć Ewangelii życia” oznacza także to, by nie bać się życia - chrześcijanin nie może być ,,aptekarzem cnoty”, „pobożnym tchórzem” czy „limfatycznym bohaterem" (E. Mounier). Przeciwnie, chrześcijanin jest człowiekiem naznaczonym dynamizmem cnoty, która obliguje do obejmowania posługą miłości ,wszystkiego i wszystkich”.

Trzeba przy tym zauważyć, za św. Janem Pawłem II, walor ekumenizmu takiego działania: „Obrona i promocja życia nie są niczyim monopolem, ale zadaniem i odpowiedzialnością wszystkich" (EV 91). Nie zmienia to wszakże faktu, że to jednak chrześcijanie powinni być pokornymi pionierami tej obrony i promocji.

\section{TO PREACH THE GOSPEL OF LIFE}

\section{Summary}

The aim of the article is to identify the main elements of the "Gospel of life" according to St. John Paul II's teaching. The Pope built the concept of the Gospel of life as a consistent response to the escalation of the culture of death. It is expressed in its deepest layer in anti-theism that leads to anti-humanism. It also means an anthropo-

${ }^{28}$ Por. np. M.L. di Pietro, Educación de la sexualidad como servicio a la vida, w: Pontifica Academia para la Vida, Comentario Interdisciplinar a la „Evangelium vitae”, red. R. Lucas Lucas, Madrid 1996 s. 639-654; F.G. Hellin, La familia, al servicio de la vida, w: Pontifica Academia para la Vida, Comentario Interdisciplinar ..., dz. cyt., s. 655-668. 
logical error, breaking the creative relationship of freedom and truth. The consequence of these views is the fight against life. In response to this program of devastation of the human life, St. John Paul II proposed in place of anti-theism the proclamation of the "Gospel of the love of God to man," which in turn allows the proclamation of the "Gospel of dignity (of the human person), which points not to todays varied category of quality of human life but to the undeniable value of life. In this way, the "Gospel of life" can be built, the proclamation of which is the priority of the mission of the Church.

Słowa kluczowe: Jan Paweł II; Evangelium vitae; kultura życia; kultura śmierci; antropologia teologiczna

Keywords: Paul II; Evangelium vitae; culture of life; culture of death; theological anthropology

\section{BIBLIOGRAFIA}

Aubert J.M., Jak żyć po chrześcijańsku w XX wieku, Warszawa 1986.

Bonora A., Człowiek obrazem Boga w Starym Testamencie, „Communio” (pol.) 2(1982), nr 2 (8) s. 3-15.

Bortkiewicz P., Obecność Chrystusa w cierpieniu, w: Miłość i cierpienie. Misterium Boga i nadzieja człowieka, red. J. Malski i I. Rutkowska, Głogów 2010, s. 96-106.

Bortkiewicz P., W stużbie życia, t. 1: Demaskacja kultury śmierci, Niepokalanów 1999.

Góralczyk P., Możliwość uwzględnienia zatożeń systemowych etyki Dietricha von Hildebranda w teologii moralnej, Poznań 1989.

Hellin F.G., La familia, al servicio de la vida, w: Pontifica Academia para la Vida, Comentario Interdisciplinar a la „Evangelium vitae”, red. R. Lucas Lucas, Madrid 1996, s. 655-668.

Hildebrand D. von, Trzy główne formy udziału człowieka $w$ wartościach, w: tenże, Serce, Poznań 1985, s. 167-198.

Jan Paweł II, Człowiek-obraz Boży jako podmiot poznania i wolności, w: Jan Paweł II, Co to znaczy wierzyć?, Warszawa 1988, s. $166-167$.

Jan Paweł II, Redemptor hominis, w: Jan Paweł II, Redemptor hominis, Tekst i komentarze, Lublin 1984, s. 7-54.

Jan Paweł II, Evangelium vitae, w: Encykliki Ojca Świętego Jana Pawła II, Kraków 2003, s. 839$-937$.

Katechizm Kościoła katolickiego, Poznań 2009².

Krąpiec M.A., Ja czlowiek, Lublin $1986^{2}$.

Pietro di M.L., Educación de la sexualidad como servicio a la vida, w: Pontifica Academia para la Vida, Comentario Interdisciplinar a la „Evangelium vitae”, red. R. Lucas Lucas, Madrid 1996, s. 639-654.

Palumbieri S., Cierpienie i sens. Między rozumem i wiara, w: Miłość i cierpienie. Misterium Boga i nadzieja człowieka, red. J. Malski i I. Rutkowska, Głogów 2010, s. 65-95.

Pytel J.K., Człowiek obrazem Boga w Nowym Testamencie, „Communio” (pol.) 2(1982) nr 2(8), s. 16-21.

Sales M., Misterium ciała ludzkiego, „Communio” 2(1982) nr 2 (8), s. 85.

Scheler M., La pudeur, Paris 1952. 
Sobór Watykański II, Konstytucja duszpasterska o Kościele w świecie współczesnym Gaudium et spes, Poznań 2005.

Styczeń T., Być soba to przekraczać siebie. O antropologii Karola Wojtyty, w: T. Styczeń, Solidarność wyzwala, Lublin 1993, s. 87-88.

Wojtyła K., Znak sprzeciwu, Paris 1980.

Rahner K., Vorgrimmler H., Natura, w: K. Rahner, H. Vorgrimmler, Maty stownik teologiczny, thum. T. Mieszkowski, P. Pachciarek, Warszawa 1987, s. 262-263.

Rosik S., Wezwanie do ludzkiej petni, w: S. Rosik, Wezwania, s. 64-66.

Salij J., Pytanie o sens cierpienia, w: Miłość i cierpienie. Misterium Boga i nadzieja człowieka, red. J. Malski i I. Rutkowska, Głogów 2010, s. 51-64.

Pawet Bortkiewicz TChr, kapłan i teolog, profesor zatrudniony na UAM w Poznaniu i WSKSiM w Toruniu, autor kilku książek i wielu artykułów, publicysta katolicki. 